\title{
An Experimental Global Prediction System for Rainfall-Triggered Landslides Using Satellite Remote Sensing and Geospatial Datasets
}

\author{
Yang Hong, Robert F. Adler, and George Huffman
}

\begin{abstract}
Landslides triggered by rainfall can possibly be foreseen in real time by jointly using rainfall intensity-duration thresholds and information related to land surface susceptibility. However, no system exists at either a national or a global scale to monitor or detect rainfall conditions that may trigger landslides due to the lack of sufficient ground-based observing network in many parts of the world. Recent advances in satellite remote sensing technology and increasing availability of highresolution geospatial products around the globe have provided an unprecedented opportunity for such a study. In this paper, a framework for developing an experimental real-time prediction system to identify where rainfall-triggered landslides will occur is proposed by combining two necessary components: surface landslide susceptibility (LS) and a real-time space-based rainfall analysis system. First, a global LS map is derived from a combination of semistatic global surface characteristics (digital elevation topography, slope, soil types, soil texture, land cover classification, etc.) using a geographic information system weighted linear combination approach. Second, an adjusted empirical relationship between rainfall intensity-duration and landslide occurrence is used to assess landslide hazards at areas with high susceptibility. A major outcome of this paper is the availability for the first time of a global assessment of landslide hazards, which is only possible because of the utilization of global satellite remote sensing products. This experimental system can be updated continuously using the new satellite remote sensing products. This proposed system, if pursued through wide interdisciplinary efforts as recommended herein, bears the promise to grow many local landslide hazard analyses into a global decisionmaking support system for landslide disaster preparedness and mitigation activities across the world.
\end{abstract}

Index Terms-Landslide, landslide susceptibility (LS), natural disasters, real-time precipitation analysis, satellite remote sensing.

\section{INTRODUCTION}

$\mathbf{L}$ ANDSLIDES are one of the most widespread natural hazards on Earth, responsible for thousands of deaths and billions of dollars in property damage every year. In the U.S.

Manuscript received June 21, 2006; revised September 1, 2006. This work was supported by NASA under the Applied Sciences Program under Steven Ambrose of NASA Headquarters.

Y. Hong is with the Goddard Earth Science Technology Center/University of Maryland Baltimore County, Baltimore, MD 21228 USA, and also with the NASA Goddard Space Flight Center, Laboratory for Atmospheres, Greenbelt, MD 20771 USA (e-mail: yanghong@agnes.gsfc.nasa.gov).

R. F. Adler is with the NASA Goddard Space Flight Center, Laboratory for Atmospheres, Greenbelt, MD 20771 USA.

G. Huffmann is with Science Systems and Applications, Inc., Lanham, MD 20706 USA, and also with the NASA Goddard Space Flight Center, Laboratory for Atmospheres, Greenbelt, MD 20771 USA.

Digital Object Identifier 10.1109/TGRS.2006.888436 alone, landslides occur in every state, causing an estimated US \$2 billion in damage and 25-50 deaths each year [1]. Annual average loss of life from landslide hazards in Japan is 170 [2]. The situation is much worse in developing countries and remote mountainous regions due to lack of financial resources and inadequate disaster management ability. Recently, a landslide, triggered by "La Nina" rains, buried an entire village on the Philippines Island of Leyte, on February 17, 2006, with at least 1800 reported deaths and only three houses left standing of the original 300. A precipitation analysis using multiple satellites [3], including the National Aeronautics and Space Administration (NASA)'s Tropical Rainfall Measuring Mission (TRMM), reported that $500 \mathrm{~mm}$ of heavy rainfall fell on that area in a ten-day period [4]. The need to develop more effective spatial coverage of landslide susceptibility (LS) and real-time hazard monitoring for vulnerable countries and remote areas remains apparent and urgent [2].

Landslides triggered by rainfall can possibly be predicted by modeling the relationship between rainfall intensity-duration and landslide occurrence [5]. Currently, no system exists at a global scale to identify rainfall conditions that may trigger landslides, largely due to lack of field-based observing networks in many parts of the world. In particular, developing countries usually lack expensive ground-based monitoring networks. Thus, for many countries around the world, remote-sensing information may be the only possible source of rainfall data and land surface characteristics available for such study. Recent advances in satellite-based precipitation observation technology and increasing availability of high-resolution geospatial products at global scale are providing an unprecedented opportunity to develop a real-time prediction system for a global view of rainfall-triggered landslides.

In this paper, a framework is proposed to develop a real-time prediction system for rainfall-triggered landslides around the globe. Drawing on the heritage of a space-based global precipitation observation system and remotely sensed surface characteristics products, this paper first derives a global susceptibility map from the geospatial datasets and then links this analysis to the dynamic trigger, real-time rainfall observations, to assess landslide hazards. The goal of this new system is to acquire a global view, rather than a site-specific view, of rainfall-triggered landslide disasters in a real-time fashion. Section II details the framework and its two major components, Section III describes case studies using a prototype of this proposed system, and Section IV presents concluding remarks and discusses future work and possible improvements. 


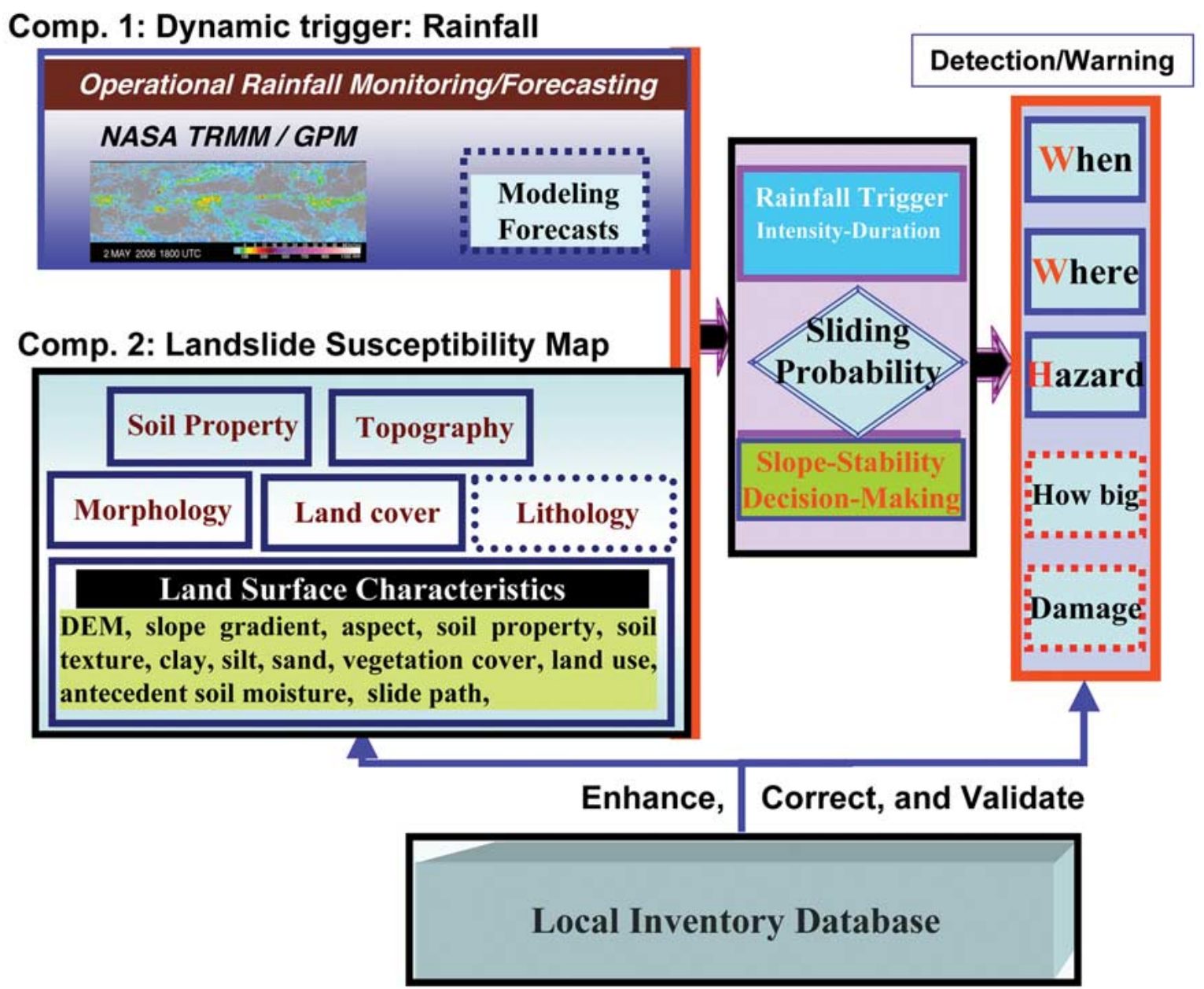

Fig. 1. Conceptual framework of real-time monitoring/warning system for rainfall-triggered landslides at global scale. Note that dashed-line boxes are important components, but not covered in this paper.

\section{Framework, DATA, AND Global LS MAP}

\section{A. Framework for Predicting Rainfall-Triggered Landslides}

In this paper, we are primarily concerned with shallow landslides that involve poorly consolidated soils or colluviums on steep hill slopes. Shallow landslides, sometimes referred to as debris flows, mudslides, mudflows, or debris avalanches, are rapidly moving flows of mixes of rocks and mud, which have the potential to kill people and destroy homes, roads, bridges, and other property. This paper addresses those landslides caused primarily by prolonged, heavy rainfall on saturated hill slopes characterized by high permeability. Rainfall-triggered landslides may mobilize into fast-moving mudflows, which generally present a greater hazard to human life than slowmoving deep-seated slides. Although most parts of the world have experienced major socioeconomic losses related to landslide activity [2], currently no system exists at either a regional or a global scale to identify rainfall conditions that may trigger landslides.

Useful assessment of landslide hazards requires, at the minimum, an understanding of both "where" and "when" that landslides may occur. As Fig. 1 shows, landslides result from a combination of factors, which according to [6] can be broadly classified into two categories, which are: 1) preparatory variables that make the land surface susceptible to failure without triggering it, such as slope, soil properties, elevation, aspect, land cover, lithology, etc. and 2) the triggering events that induce mass movement, such as heavy rainfall, and glacier outburst. For rainfall-triggered landslides, at least two conditions must be met: the areas must be susceptible to failure under certain saturated conditions, and the rainfall intensity and duration must be sufficient to saturate the ground to a sufficient depth. Therefore, to diagnose the landslide occurrence, the proposed system must link two major components: LS information and real-time precipitation analysis, as shown in Fig. 1. The LS map empirically shows part of the "where" and the rain intensityduration primarily determines the "when" information. In use, the "where" LS map is overlaid with real-time satellite-based rainfall "when" layer to detect landslide hazards as a function of time and location.

In this framework, the first-order control on the spatial distribution (the "where") of landslides is the topographic slope of the ground surface, elevation, soil types, soil texture, vegetation, and the land cover classification, while the firstorder control on the temporal distribution (the "when") of shallow landslides is the space-time variation of rainfall, which 
changes the pore-pressure response in the soil or colluviums to infiltrating water [7].

\section{B. Dynamic Trigger: Detection of Heavy Rainfall Using Satellite Observations}

The spatial distribution, duration, and intensity of precipitation play an important role in triggering landslides. A long history of development in the estimation of precipitation from space has culminated in sophisticated satellite instruments and techniques to combine information from multiple satellites to produce long-term products useful for climate monitoring [8]. A fine time resolution analysis, such as the TRMM Multisatellite Precipitation Analysis (TMPA) [3], is the key data set for the proposed landslide monitoring system in this paper. The TMPA global rainfall map is produced by using TRMM to calibrate, or adjust, the estimates from other satellite sensors, and then combining all the estimates into the TMPA final analysis. The coverage of the TMPA depends on input from different sets of sensors. First, precipitation-related passive microwave data are collected by a variety of low-earthorbit satellites, including the TRMM Microwave Imager (TMI) on TRMM, Special Sensor Microwave/Imager on Defense Meteorological Satellite Program satellites, Advanced Microwave Scanning Radiometer for the Earth Observing System (AMSR-E) on Aqua, and the Advanced Microwave Sounding Unit B on the National Oceanic and Atmospheric Administration (NOAA) satellite series. The second major data source for the TMPA is the window-channel $(\sim 10.7 \mu)$ infrared (IR) data that are being collected by the international constellation of geosynchronous Earth orbit satellites, which provide excellent time-space coverage (half-hourly $4 \times 4 \mathrm{~km}$ equivalent lat./long. grids) after merged by the Climate Prediction Center of the National Weather Service/NOAA [9]. The IR brightness temperatures are corrected for zenith-angle viewing effects and intersatellite calibration differences. Finally, the research TMPA also makes use of three additional data sources: the TRMM Combined Instrument estimate, which employs data from both TMI and the TRMM Precipitation Radar, as a source of calibration; the monthly rain gauge analysis developed by the Global Precipitation Climatology Centre (GPCC) [10]; and the Climate Assessment and Monitoring System monthly rain gauge analysis developed by [11]. The TMPA estimates are produced in four stages, which are: 1) the microwave precipitation estimates are calibrated and combined; 2) IR precipitation estimates are created using the calibrated microwave precipitation; 3 ) the microwave and IR estimates are combined; and 4) rain gauge data are incorporated.

The TMPA is a TRMM standard product at fine time and space scales and covers the latitude band $50^{\circ} \mathrm{N}-\mathrm{S}$ for the period 1998 to the delayed present. A real-time version of the TMPA merged product was introduced in February 2002 and is available on the NASA TRMM web site (http://trmm.gsfc.nasa.gov). Early validation results indicate reasonable performance at monthly scales, while at finer scales the TMPA is successful at approximately reproducing the surface-observation-based histogram of instantaneous precipitation over land, as well as reasonably detecting large daily events [3]. It is anticipated that this type of product will be continued as part of the Global Precipitation Measurement (GPM) mission (http://gpm.gsfc.nasa.gov). GPM is envisioned as improving the quality and frequency of observations from the constellation of operational and dedicated research satellites in order to provide improved global precipitation monitoring for hydrology and water resources management.

Fig. 2(a) shows a recent example of an instantaneous TMPA rain rate map downloaded from its web site. Fig. 2(b) shows climatological percentage of daily rainfall exceeding 2 in/day over land and Fig. 2(c) is the conditional daily rainfall (i.e., the average rainfall on days when it rains) averaged from eight years of TMPA rainfall data (1998-2005). The availability of this type of rainfall information quasi-globally provides an opportunity to derive empirical rainfall intensity-duration thresholds related to landslides and to examine antecedent precipitation accumulation continuously in time and space.

\section{Global LS Map}

1) Background: Previous research [12], [13] has grouped methods for LS and hazard assessment into inventory, heuristic, statistical, and deterministic approaches. A landslide inventory map can be used as an elementary form of hazard information because it shows the spatial locations of recorded landslides [14]-[20], although it fails to identify areas that may be susceptible to landsliding unless landslides have already occurred [6]. Heuristic approaches require expert opinions to estimate landslide potential from preparatory variables [21]. The reproducibility of the results and the subjectivity of weightings and ratings of the variables are the main limitations to the applicability of such models [6]. Statistical approaches according to [22] have generally taken the form of multivariate statistical analysis of landscape characteristics that have led to landslides in the past [23], [24] or a weighted hazard rating based on environmental attributes related to landsliding [18], [25]-[28]. Deterministic approaches include the modeling of physical processes involved in landsliding and therefore may better pinpoint causes of mass movement [21], [29]. However, data requirements for such physical models can often be prohibitive, leading to oversimplification of the results [6], [21], [27].

According to [22], multivariate statistics or weighted hazard ratings based on terrain factors contributing to landslides are most suitable for landslide hazard prediction at medium scale $(1: 25000-1: 50000)$. In this paper, a weighted hazard rating methodology for mapping global LS is applied. This approach considers the integration of remote sensing and geographic information system (GIS) techniques, given that most current models of the hazard prediction and landslide zonation are GIS based or with the support of GIS [22]. First, a central database collects several geospatial datasets at global scale. Second, important terrain factors contributing to landslide occurrence are derived and a numerical rating scheme for the factors is developed for spatial data analysis in GIS. Third, corresponding thematic data layers are generated and stored in GIS; and finally the global susceptibility map is computed by performing a weighted linear combination (WLC) function. The 
(a)

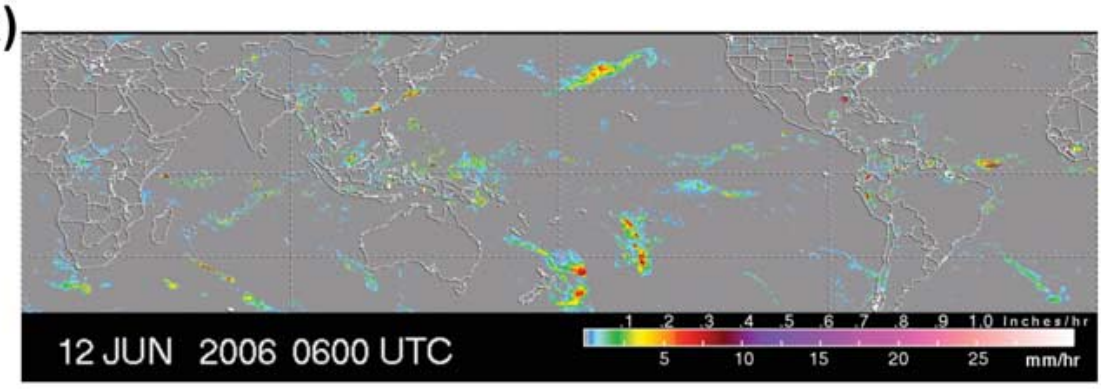

Percentage Daily Rainfall Exceeding 2 Inch/day (out of 8-Year TRMM Data)

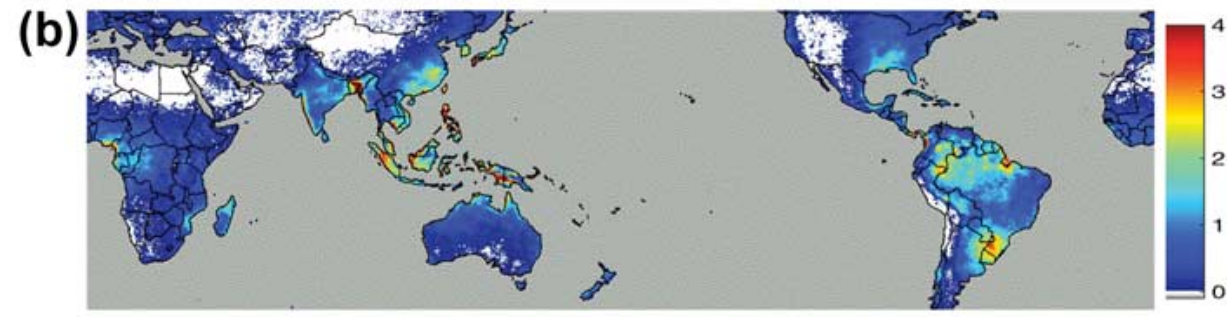

\section{Conditional Daily Rainfall of 8-year 3B42 Daily Rainfall (mm/day)}

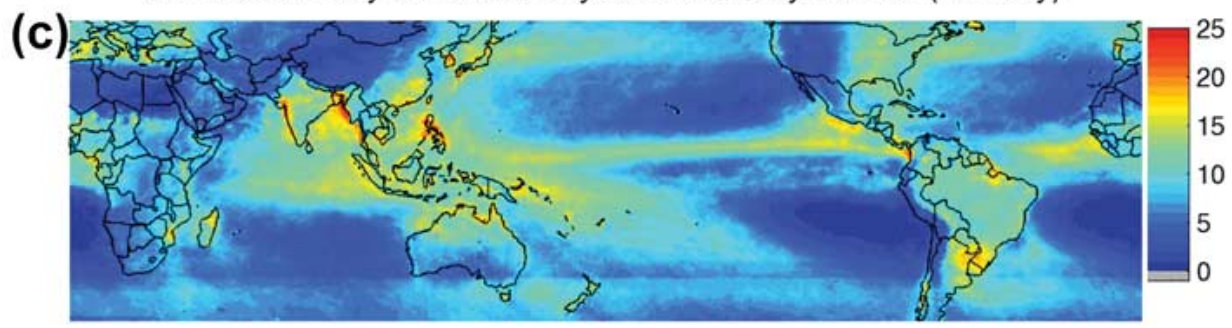

Fig. 2. NASA TRMM-based multisatellite precipitation products. (a) Real-time precipitation observations. (b) Climatological percentage of daily rainfall exceeding 2 in. (c) Conditional daily rainfall averaged from eight-year TRMM rainfall data.

resulting global LS map is classified into six relative susceptibility categories.

2) Geospatial Data Sets: Generally, scientists have found that the soil must be saturated with water for slope failure to occur. Therefore, slope steepness has the most influence on shallow landslide likelihood, followed by soil type and the soil texture of the mass material that mantles the slope, and the mechanical properties of the underlying rock. Additionally, vegetation on the slope is critical. In order to generate a LS map using these geospatial datasets, several assumptions must made: 1) the landslide occurrences can be characterized by geospatial data sets considered and 2) the landslide will occur in the future under similar geoenvironmental circumstances. The global-scale geospatial datasets used in this paper are as follows.

1) Digital elevation model (DEM) data and its derivatives. The basic DEM data sets considered in this system include NASA Shuttle Radar Topography Mission (SRTM; http://www2.jpl.nasa.gov/srtm/) and U.S. Geological Survey's GTOPO30 (http://edcdaac.usgs.gov/gtopo30/ gtopo30.html). The 30-m spatial resolution provide by SRTM data is a major breakthrough in digital mapping of the world, particularly for large portions of the developing world. DEM data are used to derive topographic factors (slope, aspect, curvature, etc.) and hydrological parameters (flow direction, flow path, etc.). All these DEM derivatives are candidates for mapping the LS map but later only slope and elevation factors are chosen by performing the numerical rating screening scheme.

2) Global Soil Property Information. Global soil property data sets are taken from Digital Soil of the World published in 2003 by the Food and Agriculture Organization of the United Nations (http://www.fao.org/AG/agl/agll/ dsmw.htm) and available in the International Satellite Land Surface Climatology Project Initiative II (ISLSCP II) Data Collection (http://www.gewex.org/islscp.html). The ISLSCP II data set provides gridded data for 18 selected soil parameters derived from data and methods developed by the Global Soil Data Task, coordinated by the Data and Information System of the International Geosphere-Biosphere Programme (IGBP), and distributed on CD-ROM by the Oak Ridge National Laboratory Distributed Active Archive Center (http://daac.ornl.gov/). The soil parameters used in this paper are soil property information (including clay mineralogy and soil depth) and 12 soil texture classes, following the U.S. Department of Agriculture soil texture classification (including sands, loam, silt, clay, and their fractions).

3) Land cover and land use data. The Moderate Resolution Imaging Spectroradiometer (MODIS) is a key instrument aboard the Terra and Aqua satellites [30]. MODIS is 
(a)

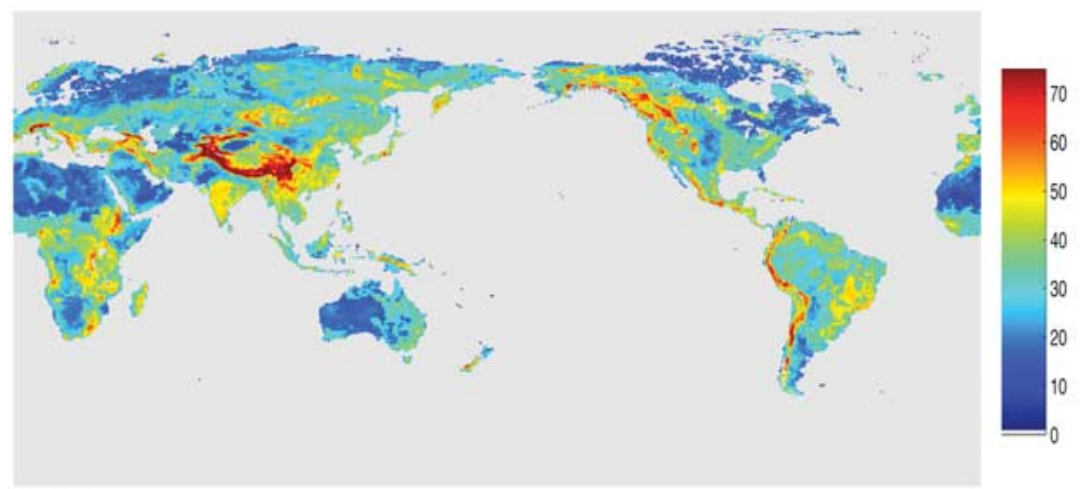

(b)

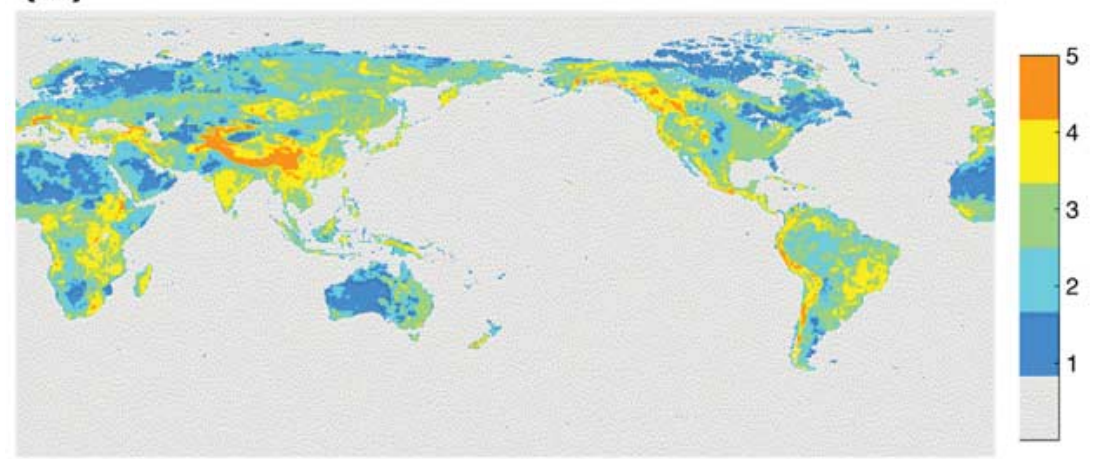

Fig. 3. (a) Global LS map derived from surface multigeospatial data. (b) The six LS categories are: 0—water bodies, permanent snow/ice; 1-very low susceptibility; 2-low susceptibility; 3-moderate susceptibility; 4-high susceptibility; and 5-very high susceptibility.

viewing the entire earth's surface every 1 to 2 days, acquiring data in 36 spectral bands, or groups of wavelengths (http://modis.gsfc.nasa.gov/index.php). The global land cover data from MODIS are used as a surrogate for vegetation and land use types. The highest resolution of the MODIS land cover classification map is $250 \mathrm{~m}$. The MODIS Land Cover Product describes the geographic distribution of the 17 IGBP land cover types based on an annual time series of observations [30].

3) Developing a Prototype Global-Scale LS Map: Most LS maps at local scales have been generated by using quantitative relationships between past landslide occurrences and spatial data sets. Since it is not feasible to collect past landslide inventory data at the global scale, an approach that considers a numerical rating scheme for the factors contributing to landslide occurrence and a WLC method to derive a final global LS map is applied in this paper. Based upon the aforementioned geospatial data sets, several terrain factors that contribute to landslide occurrences are derived, including elevation, slope, soil types (clay, loam, silt, and sand, etc.), soil texture, and land use classification. The factors have been downscaled or bilinearly interpolated to the highest SRTM spatial scale $(30 \mathrm{~m})$ in this paper. Previous studies [6], [23], [28], [31]-[36] demonstrated that these geospatial parameters are closely associated with landslide occurrences and found that a combination of elevation and slope best portrayed LS [36]. Similarly, [34] reported that three data layers (slope, elevation, and aspect) derived exclusively from a DEM provided better results than six data layers (including other lithology, surficial materials, and land use). Their results [34], [36] indicated that topography was the dominant control in determining location of landslide occurrence. The effect of slope on landslides was documented in [6] and [32]. They reported slope steepness has the most influence on shallow landslide likelihood, followed by soil texture and soil types that mantle the slope. In many regions, elevation is approximately a proxy for mean rainfall that increases with height due to orographic effects and high elevation areas are probably preferentially susceptible to landslides because they receive greater amounts of rainfall than areas at lower elevations [36]. Vegetation on the slope is critical because bare slopes are especially vulnerable to erosion and mass wasting, but slopes with lush, healthy vegetation are far more resistant [31]. In addition, land cover can be classified into five classes, which are: 1) forested land; 2) shrub land; 3) grass land; 4) pasture and cropland; and 5) developed land and road corridors [31], which describe a continuum of increasing susceptibility (e.g., from zero to one) to landslides.

Following the above analysis, we first classified each landslide-controlling factor into various categories. For example, according to [31], the MODIS land cover types can be assigned susceptibility values from zero to one at the order of increasing LS, respectively. Assignment of LS values for other parameters is based on several empirical assumptions, which are: 1) higher slope, higher susceptibility; 2) coarse and shallow soil is more susceptible than fine and deep soil; and 
TABLE I

GLobal Distribution of LS CATEgories

\begin{tabular}{|l|l|l|l|l|l|l|}
\hline Category & 0 & 1 & 2 & 3 & 4 & 5 \\
\hline Values & 0 & $0 \sim 20$ & $21 \sim 34$ & $35 \sim 55$ & $56 \sim 79$ & $>80$ \\
\hline Susceptibility & Water/snow/ice & Very low & Low & Moderate & High & Very high \\
\hline$\%$ (globe) & 77.9 & 4.5 & 6.1 & 6.8 & 4.1 & 0.6 \\
\hline$\%($ land) & -- & 20.3 & 27.5 & 30.8 & 18.6 & 2.8 \\
\hline
\end{tabular}

TABLE II

TRMM PRECIPITATION ACCUMULATION AND LSM INFO FOR LANDSLIDE CASES

\begin{tabular}{|c|c|c|c|c|c|}
\hline Time & $\begin{array}{c}\text { Country } \\
\text { (State/Province) }\end{array}$ & Causes/types & $\begin{array}{l}\text { Susceptibility } \\
\text { category }\end{array}$ & $\begin{array}{c}\text { TRMM } \\
\text { Rainfall } \\
\text { accumulation }\end{array}$ & Impact \\
\hline $04 / 13 / 2006$ & $\begin{array}{c}\text { Buenaventura, } \\
\text { Colombia }\end{array}$ & Storm & High & $103 \mathrm{~mm} /$ day & $>34$ death \\
\hline $03 / 25 / 2006$ & Oahu, Hawaii & Storm & Very high & $450 \mathrm{~mm} / 7$ day & Unknown \\
\hline $2 / 17 / 2006$ & Leyte, Philippines & Storm & High & $400 \mathrm{~mm} / 5$ day & $\begin{array}{l}>1500 \\
\text { death }\end{array}$ \\
\hline $01 / 04 / 2006$ & Jakarta, Indonesia & $\begin{array}{c}\text { Monsoon } \\
\text { rains. }\end{array}$ & High & $250 \mathrm{~mm} / 3$ day & $\begin{array}{l}>200 \\
\text { buried }\end{array}$ \\
\hline $10 / 08 / 2005$ & Solola, Guatemala & Hurricane Stan & High & $300 \mathrm{~mm} / 3$ day & $\begin{array}{c}>1800 \\
\text { death } \\
\end{array}$ \\
\hline $09 / 05 / 2005$ & $\begin{array}{l}\text { Yuexi County, } \\
\text { Anhui, China }\end{array}$ & Rain storm & High & \multicolumn{2}{|c|}{$\begin{array}{c}450 \mathrm{~mm} / 6 \text { day } \\
\text { Affected } 210,000 \text { people; } \\
\text { Flattened } 10,000 \text { houses }\end{array}$} \\
\hline $08 / 25 / 2005$ & Guwahati, India & Rain & High & $310 \mathrm{~mm} / 3$ day & 5 killed \\
\hline $04 / 13 / 2005$ & Santa Cruz, CA & Storm & High & $147 \mathrm{~mm} /$ day & 2 death \\
\hline $1 / 10 / 2005$ & La Conchita, CA & $\begin{array}{c}\text { Heavy rain } \\
\text { season }\end{array}$ & High & $390 \mathrm{~mm} / 14$ day & 12 death \\
\hline $11 / 13 / 2003$ & Puerto Rico & Hurricane & High & $145 \mathrm{~mm} /$ day & Unknown \\
\hline $06 / 05 / 2001$ & Puerto Rico & Tropical storm & High & $77 \mathrm{~mm} /$ day & Unknown \\
\hline $05 / 06 / 2000$ & Puerto Rico & Tropical storm & High & $258 \mathrm{~mm} / 2$ day & Unknown \\
\hline 08/22/1999 & Puerto Rico & $\begin{array}{c}\text { Hurricane } \\
\text { Debby }\end{array}$ & High & $255 \mathrm{~mm} / 3$ day & Unknown \\
\hline $10 / 30 / 1998$ & Nicaragua & $\begin{array}{l}\text { hurricane } \\
\text { Mitch }\end{array}$ & Very high & $720 \mathrm{~mm} / 6$ day & $\begin{array}{l}>2000 \\
\text { death }\end{array}$ \\
\hline $09 / 22 / 1998$ & Puerto Rico & Hurricane & High & $450 \mathrm{~mm} / 3$ day & Unknown \\
\hline
\end{tabular}

3) higher elevation, higher susceptibility. Under assumption 1), for example, the slope map units are given zero susceptibility value for the class of flat slopes and susceptibility value one is assigned to the class of steepest slopes. After assignment of the numerical values to every landslide-controlling factor, the second step is to generate thematic data layers and to store (overlay) these layers in a GIS system. The last step is to derive the final susceptibility values by performing a WLC function. WLC is a method where landslide-controlling factors can be combined by applying primary- and second-level weights [37]. Among the five parameters, the slope is the most important factor and soil types and soil texture are also primary-level parameters, while the elevation and land cover types are of secondary-level importance, based on the above analysis and previous studies [6], [12]-[36]. Thus, the preliminary weight determination for the five parameters was chosen as $0.4,0.2$, $0.2,0.1$, and 0.1 for slope, soil type, soil texture, elevation, and land cover types, respectively, in this paper. The choice of these weights is also referred to [35, Table II]. The consequent range in susceptibility values is normalized from zero to 100 , as shown in Fig. 3(a). The larger the susceptibility value, the greater the landslide potential at that location.

The LS values are then classified into several LS categories [35]. A judicious way for such classification is to search for abrupt changes in values [38]. The category boundaries are drawn at significant changes in the histogram of the LS val- (a)

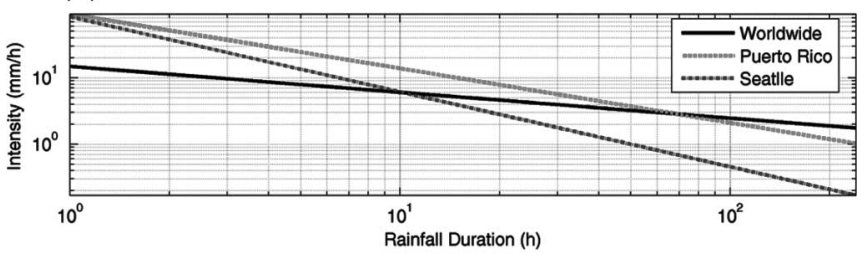

(b)

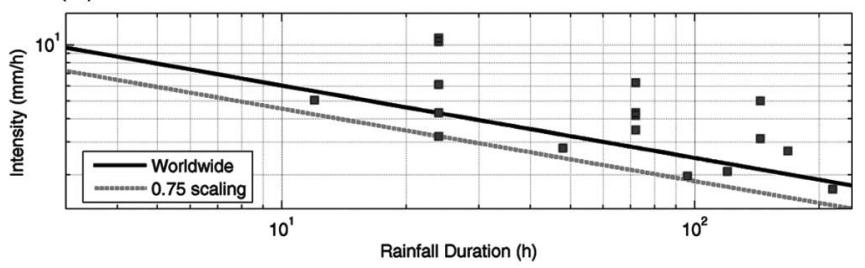

Fig. 4. (a) Regional or worldwide empirical rainfall intensity-duration thresholds triggering landslides derived from Godt (2004) for Seattle, Larsen and Simon (1993) for Puerto Rico, and Caine (1980) for worldwide, respectively; (b) the lower bound of rainfall intensity-duration threshold (dashed-line: Intensity $=11.115$ Duration-0.39) for several landslides (squares) that occurred in the TRMM operation period (1998-2005) is approximately 0.75 of the global algorithm from Caine 1980 (dark line).

ues. As a result, the global LS map is finally classified into six categories: 0-water bodies or permanent ice and snow, 1-very low, 2-low, 3-moderate, 4-high, and 5-very high susceptibility. The very high and high susceptibility categories 
TABLE III

Antecedent Rainfall ACCumulation: LANDSlide Triggering Thresholds (Millimeters)

\begin{tabular}{|l|l|l|l|l|l|l|l|l|l|l|l|}
\hline $\begin{array}{l}\text { Duration } \\
\text { Accumulation }\end{array}$ & $\mathbf{1 2 h}$ & $\mathbf{2 4 h}$ & $\mathbf{4 8 h}$ & $\mathbf{7 2 h}$ & $\mathbf{9 6 h}$ & $\mathbf{1 2 0 h}$ & $\mathbf{1 4 4 h}$ & $\mathbf{1 6 8 h}$ & $\mathbf{1 9 2 h}$ & $\mathbf{2 1 6 h}$ & $\mathbf{2 4 0 h}$ \\
\hline Caine 1980 & 67.5 & 102.9 & 157.2 & 201.3 & 239.9 & 274.9 & 307.2 & 337.5 & 366.1 & 393.4 & 419.5 \\
\hline $\mathbf{0 . 7 5}$ scaling & 50.625 & 77.175 & 117.9 & 150.975 & 179.925 & 206.175 & 230 & 252.9 & 274.58 & 294 & 314.25 \\
\hline Used & 50 & 75 & 120 & 150 & 180 & 200 & 230 & 250 & 275 & 300 & 315 \\
\hline
\end{tabular}

account for $2.8 \%$ and $18.6 \%$ of land areas, as shown in Table I. Fig. 3(b) demonstrates the hot spots of the high landslide potential regions: the Pacific Rim, the Alps, the Himalayas and South Asia, Rocky Mountains, Appalachian Mountains, and parts of the Middle East and Africa. India, China, Nepal, Japan, the USA, and Peru are shown to be landslide-prone countries. These results are similar to those reported by [2].

\section{EXPERIMENTAl Prediction System FOR RAINFALL-TRIGGERED LANDSLIDES}

\section{A. Linking Rainfall Data With LS}

There is a direct relationship between rainfall levels and the occurrence of landslides [39], which, in return, depends on the properties of the soil surface [40]. This paper links the global LS map with the frequently updated satellite-based precipitation information to identify when areas with high landslide potential are receiving heavy rainfall. Table II lists several major landslides over the NASA TRMM operational period (1998-present). The rainfall totals are accumulated from the TRMM database and the sliding susceptibility category is taken from the global LS map [Fig. 3(b)]. Despite variations among the cases, the production of shallow landslides obviously requires intense rainfall, sustained for at least a brief period of time, in areas with susceptibility category of "high" or above.

\section{B. Global-Scale Experimental Prediction System for Rainfall-Triggered Landslides}

Landslide hazard assessment based on relationships with rainfall intensity-duration has been applied at both global [41] and regional scales [42]-[44]. As shown in Fig. 4(a), empirical rainfall intensity-duration thresholds have been developed for Seattle [44], Puerto Rico [43], and worldwide [41]. The squares in Fig. 4(b) indicate the rainfall intensity-duration plots of landslide cases that occurred within the TRMM observation period (1998-current). The lower bound of rainfall intensityduration threshold can be approximately identified if a scaling factor, 0.75, is applied to the worldwide threshold from [41]. We believe that the reason for a scaling factor is the coarse resolution of global rainfall data being used, $25 \mathrm{~km}$. Table III lists the thresholds of rainfall accumulation triggering landslides according to the worldwide threshold [41] and the 0.75-scaled threshold (e.g., Intensity $=11.115$ Duration $^{-0.39}$ ). When coupled with real-time rainfall data, such rainfall intensity-duration thresholds can provide the basis for early warning systems for shallow landslides [45]. An experimental prediction system for real-time landslide hazard assessment based on the adjusted rainfall intensity-duration threshold has been developed from these concepts and a trial version of this operational system is displayed on the NASA TRMM website (http://trmm.gsfc.nasa.gov/publications_dir/_landslide.html). Accumulations of the real-time TMPA precipitation for various time intervals are computed and compared with the rainfall intensity-duration thresholds [Fig. 4(b) and Table III] every $3 \mathrm{~h}$. Those locations receiving rainfall exceeding the intensityduration thresholds are marked as a landslide hazard zone if the underlying susceptibility category is "high" or "very high" at that location. The locations and timing of predicted landslides can then be checked against first-hand accounts from the field or validated by later news reports.

This experimental global prediction system for rainfalltriggered landslides is initially evaluated by comparing with reported landslide occurrences within the eight-year TRMM operational time period. For example, one landslide case was predicted by this experimental system on April 13, 2006, in Colombia. The rainfall accumulation for the previous $24 \mathrm{~h}$ was $103 \mathrm{~mm}$ over central Colombia and the LS map indicates susceptibility category high at this area, so the landslide hazard is color-coded as red on the web-based graphical interface. Later news reports indicated that at least 34 people were missing and four villages were destroyed in a landslide near the Pacific port city of Buenaventura in southwestern Colombia. Table IV lists 25 landslide occurrences collected from worldwide news reports, the TRMM website, and other sources. The calculated probability of detection is $0.76,19$ successful detections out of total 25 occurrences (Table IV). Among the six failures, three cases are caused by short-term heavy rainfall, two cases are by heavy rainfall on snow or snow melting, and one case is due to monsoon rainfall in India. This also demonstrates that the current algorithm does not work well for landslides triggered by very intense rainfall in a relatively short time period (i.e., less than $12 \mathrm{~h}$ ) or by processes involving rapid snow melting.

\section{SUMmary AND DISCUSSION}

The primary criteria which influence shallow landslides are precipitation intensity, slope, soil type, elevation, vegetation, and land cover type. Drawing on recent advances in remote sensing technology and the abundance of global geospatial products, this paper proposed a conceptual framework for a real-time prediction system (Fig. 1) for rainfall-triggered landslides across the globe. This system combines the NASA TMPA precipitation information (Fig. 2; http://trmm.gsfc.nasa.gov) and land surface characteristics to assess landslides. First, a prototype of a global LS map (Fig. 3 and Table I) is produced using NASA SRTM and U.S. Geological Survey GTOPO30 DEM, DEM derivatives such as slope, soil-type 
TABLE IV

EVALUATION OF THE EXPERIMENTAL SYSTEM BY RETROSPECTIVELY COMPARING WITH REPORTED WORLDWIDE LANDSLIDES WitHIN LAST EIGHT-YEAR TRMM OPERATIONAL PERIOD

\begin{tabular}{|c|c|c|c|c|}
\hline Time & $\begin{array}{c}\text { Country } \\
\text { (State/Province) }\end{array}$ & $\begin{array}{l}\text { Detected (YES) } \\
\text { or failed (NO) }\end{array}$ & Causes/types & $\begin{array}{c}\text { Major losses and } \\
\text { damage }\end{array}$ \\
\hline $\begin{array}{l}\text { Aug. 22, } \\
2006\end{array}$ & $\begin{array}{l}\text { Ban Thahan Village in } \\
\text { Phang Nga, } \\
\text { Thailand }\end{array}$ & NO & Heavy Rainfall/flash Flood & Blocking the roads \\
\hline $\begin{array}{l}\text { Aug. 20, } \\
2006\end{array}$ & $\begin{array}{l}\text { Holiday village of } \\
\text { Gulval in Cornwall, } \\
\text { UK }\end{array}$ & YES & Heavy shower, & Unknown \\
\hline $\begin{array}{l}\text { Aug. 20, } \\
2006\end{array}$ & Surat Thani, Thailand & YES & Heavy rainfall and flash flood & 600 residents evacuated \\
\hline $\begin{array}{l}\text { Aug. 19, } \\
2006\end{array}$ & $\begin{array}{l}\text { Song Bang town of } \\
\text { northern mountainous } \\
\text { Cao Bang province, } \\
\text { Vietnam }\end{array}$ & YES & $\begin{array}{l}\text { caused by prolonged heavy } \\
\text { rains }\end{array}$ & 10 killed \\
\hline $\begin{array}{l}\text { Jul. 31, } \\
2006\end{array}$ & $\begin{array}{l}\text { Roer Gulch east of } \\
\text { Telluride, CO, USA }\end{array}$ & NO & Heavy rainfall/flash flood & Unknown \\
\hline Jul. 9 & South Korea & YES & Typhoon Ewiniar, $>300 \mathrm{~mm}$ & Widespread mudslide \\
\hline $\begin{array}{l}\text { Jun. } 28, \\
2006\end{array}$ & Albany, upstate of NY & YES & $\begin{array}{l}\text { Heavy rainfall, } 400 \mathrm{~mm} / 5 \\
\text { days }\end{array}$ & 2 killed \\
\hline $\begin{array}{l}\text { Jun. } 25 \text {, } \\
2006\end{array}$ & $\begin{array}{l}\text { Villages of Chamba } \\
\text { District, Shimla, India }\end{array}$ & NO & Strom, flash flood & Six houses swept away \\
\hline $\begin{array}{l}\text { Jun. 20, } \\
2006\end{array}$ & $\begin{array}{l}\text { Sinjai in South Island } \\
\text { of Sulawesi } \\
\text { Indonesian }\end{array}$ & YES & Heavy rainfall $>250 \mathrm{~mm}$ & $>200$ deaths \\
\hline $\begin{array}{l}\text { May 17, } \\
2006\end{array}$ & $\begin{array}{l}\text { The Schweitzer } \\
\text { Mountain Ski resort, } \\
\text { Sandpoint, Idaho }\end{array}$ & NO & $\begin{array}{l}\text { Rain on snow and snowmelt, } \\
\text { Rocks, mudslide, and debris } \\
\text { flows }\end{array}$ & Condo buildings damaged \\
\hline $\begin{array}{l}\text { Apr. 13, } \\
2006\end{array}$ & $\begin{array}{l}\text { Buenaventura, } \\
\text { Colombia }\end{array}$ & YES & Rain storm, $103.04 \mathrm{~mm} /$ day & $>34$ death \\
\hline $\begin{array}{l}\text { Jan. 04, } \\
2006\end{array}$ & Jakarta, Indonesia & YES & Monsoon rains, $250 \mathrm{~mm} / 3 \mathrm{day}$ & $>200$ buried \\
\hline $\begin{array}{l}\text { Oct. 8, } \\
2005\end{array}$ & Solola, Guatemala & YES & Hurricane Stan, $300 \mathrm{~mm} / 3$ day & $>1800$ death \\
\hline Sep. 5, 2005 & $\begin{array}{l}\text { Yuexi County, } \\
\text { Anhui, China }\end{array}$ & YES & Rain storm, $450 \mathrm{~mm} / 6 \mathrm{day}$ & $\begin{array}{l}210,000 \text { people affected; } \\
10,000 \text { houses flattened }\end{array}$ \\
\hline $\begin{array}{l}\text { Aug. 5, } \\
2005\end{array}$ & Guwahati, India & NO & Monsoon Rain, 310mm/3day & 5 killed \\
\hline $\begin{array}{l}\text { Jan. } 10, \\
2005\end{array}$ & La Conchita, CA & YES & $\begin{array}{l}\text { Heavy rain season, } \\
390 \mathrm{~mm} / 14 \text { day }\end{array}$ & 12 death \\
\hline Oct., 2004 & $\begin{array}{l}\text { Miyagawa area, Mie } \\
\text { prefecture, Japan }\end{array}$ & YES & $\begin{array}{l}\text { Heavy and intense rainfall; } \\
\text { Numerous landslides and } \\
\text { debris flow }\end{array}$ & $\begin{array}{l}17 \text { deaths, } 9 \text { injuries; } 87 \\
\text { homes damaged/; extensive } \\
\text { forest damage }\end{array}$ \\
\hline $\begin{array}{l}\text { Jul. 20, } \\
2003\end{array}$ & $\begin{array}{l}\text { Minamata and } \\
\text { Hishikari, southern } \\
\text { Kyushu, Japan }\end{array}$ & YES & $\begin{array}{l}\text { Heavy and intense rainfall; } \\
\text { Debris avalanches and debris } \\
\text { flows }\end{array}$ & $\begin{array}{l}25 \text { deaths; } 7 \text { homes } \\
\text { destroyed; roads, power and } \\
\text { hot spring lines damaged }\end{array}$ \\
\hline May 2003 & $\begin{array}{l}\text { Ratnapura and } \\
\text { Hambantota Districts, } \\
\text { Sri Lanka }\end{array}$ & YES & $\begin{array}{l}\text { Continual heavy rains; } \\
\text { Many landslides and debris } \\
\text { flows }\end{array}$ & $\begin{array}{l}>260 \text { deaths; }>24,000 \\
\text { homes/schools destroyed; } \\
180,000 \text { families homeless }\end{array}$ \\
\hline $\begin{array}{l}\text { May 11, } \\
2003\end{array}$ & $\begin{array}{l}\text { Southwest Guizhou } \\
\text { Province, China }\end{array}$ & YES & $\begin{array}{l}\text { Heavy rainfall and road } \\
\text { construction; road-related } \\
\text { landslides }\end{array}$ & $\begin{array}{l}35 \text { road workers killed and } 2 \\
\text { buildings and road } \\
\text { destroyed }\end{array}$ \\
\hline $\begin{array}{l}\text { Apr. 20, } \\
2003\end{array}$ & $\begin{array}{l}\text { Kara Taryk, } \\
\text { Kyrgyzstan }\end{array}$ & NO & $\begin{array}{l}\text { Rain-on-snow; large } \\
\text { landslides in Soviet-era } \\
\text { uranium mining area }\end{array}$ & $\begin{array}{l}38 \text { deaths; } 13 \text { homes } \\
\text { destroyed; potential } \\
\text { pollution of a river }\end{array}$ \\
\hline $\begin{array}{l}\text { Dec. 14-16, } \\
1999\end{array}$ & $\begin{array}{l}\text { North coast of } \\
\text { Venezuela near Carcas }\end{array}$ & YES & $\begin{array}{l}\text { Nearly } 1000 \mathrm{~mm} / 3 \text { days; } \\
\text { Widespread shallow } \\
\text { landslides and debris flows } \\
\text { along a } 40-\mathrm{km} \text { coastal strip }\end{array}$ & $\begin{array}{l}\text { About } 30,000 \text { deaths; } 8,700 \\
\text { residences destroyed; } \\
\text { extreme infrastructure } \\
\text { damage }\end{array}$ \\
\hline $\begin{array}{l}\text { Oct. 30, } \\
1998 \\
\end{array}$ & $\begin{array}{l}\text { Casita Volcano, } \\
\text { Nicaragua }\end{array}$ & YES & $\begin{array}{l}\text { hurricane Mitch, } \\
720 \mathrm{~mm} / 6 \text { day }\end{array}$ & $>2000$ death \\
\hline $\begin{array}{l}\text { Aug. 26-31, } \\
1998\end{array}$ & $\begin{array}{l}\text { Nishigo, shirakawa, } \\
\text { and Nasu, Japan }\end{array}$ & YES & $\begin{array}{l}5 \text { days of heavy rainfall; } \\
>1000 \text { landslides }\end{array}$ & $\begin{array}{l}9 \text { deaths; many } \\
\text { homes/buildings destoryed }\end{array}$ \\
\hline $\begin{array}{l}\text { Aug. 17, } \\
1998\end{array}$ & $\begin{array}{l}\text { Malpa, Northern } \\
\text { India }\end{array}$ & YES & $\begin{array}{l}4 \text { days of heavy rainfall; } \\
\text { Large rockfall/debris } \\
\text { avalanche }\end{array}$ & $\begin{array}{l}207 \text { deaths; } 5.2 \text { million } \\
\text { rupees direct cost and } 0.5 \\
\text { million rupees indirect cost }\end{array}$ \\
\hline
\end{tabular}

information downscaled from the Digital Soil Map of the World (sand, loam, silt, or clay, etc.), soil texture, and MODIS land cover classification. Second, this map is overlaid with satellitebased observations of rainfall intensity-duration [Fig. 4(b) and Table III], to identify the location and time of landslide hazards when areas with significant LS are receiving heavy rainfall. The effectiveness of this system is compared to several recent land- slide events that occurred during the TRMM operational period (Table IV). A major outcome of this paper is the availability of a global prospective on rainfall-triggered landslide disasters, only possible because of the utilization of global satellite products. This type of real-time prediction system for disasters could provide policy planners with overview information to assess the spatial distribution of potential landslides. However, ultimate 
decisions regarding site-specific LS will continue to be made only after a site inspection.

A global evaluation of this system is underway through comparison with various field databases, web sites, and news reports of landslide disasters. The need for retrospective validation and improvement of this experimental system requires continued collection of global landslide data. The prototype of this system can be enhanced by providing improved satellite remote sensing products and by updating the geospatial database as more relevant information becomes available. Specifically, the land cover data should be routinely updated because they are subject to change by human activity. Several future activities are under consideration.

1) More information, such as geologic factors, could be incorporated into this global LS when they become available globally.

2) Finer resolution DEM data such as $6.1 \times 6.1 \mathrm{~m}$ LIDARbased data can also improve the LS mapping, even if only available over small areas.

3) Soil moisture conditions observed from NASA Aqua satellite with the AMSR-E instrument or an antecedent precipitation index accumulated from TRMM will be examined for usefulness in this experimental landslide detection/warning system.

4) The empirical rainfall intensity-duration threshold triggering landslides may be regionalized using mean climatic variables (e.g., mean annual rainfall).

Given the fact that landslides usually occur after a period of heavy rainfall, a real-time landslide prediction system can be readily transformed into an early warning system by making use of the time lag between rainfall peak and slope failure. Therefore, success of this prototype system bears promise as an early warning system for global landslide disaster preparedness and hazard management. Additionally, it is possible that the warning lead time of global landslide forecasts can be extended by using rainfall forecasts (1-10 days) from operational numerical weather forecast models. This real-time prediction system bears the promise to extend current local landslide hazard analyses into a global decision-making support system for landslide disaster preparedness and mitigation activities across the world.

\section{REFERENCES}

[1] USGS (United States Geological Survey) Report, 2006. [Online]. Available: http://landslides.usgs.gov/

[2] R. C. Sidle and H. Ochiai, Landslide Processes, Prediction, and Land Use. Washington, DC: Amer. Geophys. Union, 2006, pp. 1-312.

[3] G. J. Huffman, R. F. Adler, D. T. Bolvin, G. Gu, E. J. Nelkin, K. P. Bowman, Y. Hong, E. F. Stocker, and D. B. Wolff, "The TRMM multi-satellite precipitation analysis: Quasi-global, multi-year, combinedsensor precipitation estimates at fine scale," J. Hydrometeorol., 2006, to be published.

[4] A. M. A. Lagmay, J. B. T. Ong, D. F. D. Fernandez, M. R. Lapus, R. S. Rodolfo, A. M. P. Tengonciang, J. L. A. Soria, E. G. Baliatan, Z. L. Quimba, C. L. Uichanco, E. M. R. Paguican, A. R. C. Remedio, G. R. H. Lorenzo, W. Valdivia, and F. B. Avila, "Scientists investigate recent Philippine landslide," EOS Trans. Amer. Geophys. Union, vol. 87, no. 12 , p. 121,2006

[5] D. K. Keefer and R. C. Wilson, "Real-time landslide warning during heavy rainfall," Science, vol. 238, no. 13, pp. 921-925, 1987.
[6] F. C. Dai and C. F. Lee, "Landslide characteristics and slope instability modeling using, GIS Lantau Island, Hong Kong," Geomorphology, vol. 42, no. 3/4, pp. 213-238, Jan. 2002.

[7] R. M. Iverson, "Landslide triggering by rain infiltration," Water Resour. Res., vol. 36, no. 7, pp. 1897-1910, Jul. 2000.

[8] R. F. Adler, G. J. Huffman, A. Chang, R. Ferraro, P. Xie, J. Janowiak, B. Rudolf, U. Schneider, S. Curtis, D. Bolvin, A. Gruber, J. Susskind, and P. Arkin, "The version 2 Global Precipitation Climatology Project (GPCP) monthly precipitation analysis (1979-present)," J. Hydrometeorol., vol. 4, no. 6, pp. 1147-1167, 2003.

[9] J. E. Janowiak, R. J. Joyce, and Y. Yarosh, "A real-time global half-hourly pixel-resolution IR dataset and its applications," Bull. Amer. Meteorol. Soc., vol. 82, no. 2, pp. 205-217, Feb. 2001

[10] B. Rudolf, "Management and analysis of precipitation data on a routine basis," in Proc. Int. Symp. Precip. and Evap., B. Sevruk and M. Lapin, Eds. Bratislava, Slovakia: Slovak Hydrometeor. Inst., Sep. 20-24, 1993, vol. 1, pp. 69-76.

[11] P. Xie and P. A. Arkin, "Gauge-based monthly analysis of global land precipitation from 1971 to 1994," J. Geophys. Res., vol. 101, no. D14, pp. 19023-19034, Aug. 1996.

[12] R. Soeters and C. van Westen, "Slope instability, recognition, analysis and zonation," in Landslides: Investigation and Mitigation, vol. 247, A. Turner and R. Schuster, Eds. Washington, DC: Transp. Res. Board, 1996, pp. 129-177.

[13] C. van Westen, N. Rengers, M. Terlien, and R. Soeters, "Prediction of the occurrence of slope instability phenomena through GIS-based hazard zonation," Geol. Rundsch., vol. 86, no. 2, pp. 404-414, Aug. 1997.

[14] Y. He, H. Xie, P. Cui, F. Wei, D. Zhong, and J. Gardner, "GIS-based hazard mapping and zonation of debris flows in Xiaojiang Basin, Southwestern China," Environ. Geol., vol. 45, no. 2, pp. 285-293, Dec. 2003.

[15] F. Mantovani, R. Soeters, and C. van Westen, "Remote sensing techniques for landslide studies and hazard zonation in Europe," Geomorphology, vol. 15, no. 3/4, pp. 213-225, Apr. 1996.

[16] G. Wieczorek, "Preparing a detailed landslide-inventory map for hazard evaluation and reduction," Bull. Assoc. Eng. Geol., vol. 21, no. 3, pp. 337 342, 1984.

[17] R. Nagarajan, A. Mukherjee, A. Roy, and M. Khire, "Temporal remote sensing data and GIS application in landslide hazard zonation of part of Western Ghat, India," Int. J. Remote Sens., vol. 19, no. 4, pp. 573-585, Mar. 1998.

[18] C. Zhou, C. Lee, J. Li, and Z. Xu, "On the spatial relationship between landslides and causative factors on Lantau Island, Hong Kong," Geomorphology, vol. 43, no. 3/4, pp. 197-207, Mar. 2002.

[19] C. van Westen and F. Getahun, "Analyzing the evolution of the Tessina landslide using aerial photographs and digital elevation models," Geomorphology, vol. 54, no. 1, pp. 77-89, Aug. 2003.

[20] K. Cheng, C. Wei, and S. Chang, "Locating landslides using multitemporal satellite images," Adv. Space Res., vol. 33, no. 3, pp. 296-301, 2004.

[21] J. Barredo, A. Benavides, J. Hervás, and C. van Westen, "Comparing heuristic landslide hazard assessment techniques using GIS in the Tirajana basin, Gran Canaria Island, Spain,” Int. J. Appl. Earth Obs. Geoinf., vol. 2, no. 1, pp. 9-23, 2000.

[22] G. Metternicht, H. Lorenz, and G. Radu, "Remote sensing of landslides: An analysis of the potential contribution to geo-spatial systems for hazard assessment in mountainous environments," Remote Sens. Environ., vol. 98, no. 2/3, pp. 284-303, Oct. 2005.

[23] A. Carrara, M. Cardinali, R. Detti, F. Guzzetti, V. Pasqui, and P. Reichenbach, "GIS techniques and statistical models in evaluating landslide hazard," Earth Surf. Process. Landf., vol. 16, no. 5, pp. 427445, 1991.

[24] A. Lorente, J. Garcia-Ruiz, S. Begueria, and J. Arnaéz, "Factors explaining the spatial distribution of hillslope debris flows," Mt. Res. Dev., vol. 22 , no. 1 , pp. 32-39, 2002

[25] L. Donati and M. C. Turrini, "An objective method to rank the importance of the factors predisposing to landslides with the GIS methodology: Application to an area of the Apennines (Valnerina: Perugia, Italy)," Eng. Geol., vol. 63, no. 3, pp. 277-289, Mar. 2002.

[26] P.-S. Lin, J.-Y. Lin, H.-C. Hung, and M.-D. Yang, "Assessing debris flow hazard in a watershed in Taiwan," Eng. Geol., vol. 66, no. 3, pp. 295-313, Nov. 2002.

[27] M. L. Gritzner, W. Marcus, R. Aspinall, and S. Custer, "Assessing landslide potential using GIS, soil wetness modeling and topographic attributes, Payette River, Idaho," Geomorphology, vol. 37, no. 1, pp. 149-165, Mar. 2001

[28] R. Anbalagan, "Landslide hazard evaluation and zonation mapping in mountainous terrain,” Eng. Geol., vol. 32, no. 4, pp. 269-277, Jul. 1992. 
[29] D. Miller, "Coupling GIS with physical models to assess deep-seated landslide hazards," Environ. Eng. Geosci., vol. I, no. 3, pp. 263-276, 1995.

[30] M. A. Friedl, D. K. McIver, J. C. F. Hodges, X. Y. Zhang, D. Muchoney, A. H. Strahler, C. E. Woodcock, S. Gopal, A. Schneider, A. Cooper, A. Baccini, F. Gao, and C. Schaaf, "Global land cover mapping from MODIS: Algorithms and early results," Remote Sens. Environ., vol. 83, no. 1/2, pp. 287-302, Nov. 2002.

[31] M. C. Larsen and A. J. Torres Sanchez, "The frequency and distribution of recent landslides in three montane tropical regions of Puerto Rico," Geomorphology, vol. 24, no. 4, pp. 309-331, Sep. 1998.

[32] S. Lee and K. Min, "Statistical analysis of landslide susceptibility at Yongin, Korea," Environ. Geol., vol. 40, no. 9, pp. 1095-1113, 2001.

[33] A. K. Saha, R. P. Gupta, and M. K. Arora, "GIS-based landslide hazard zonation in the Bagirathi (Ganga) Valley, Himalayas," Int. J. Remote Sens., vol. 23, no. 2, pp. 357-369, Jan. 2002.

[34] A. G. Fabbri, C. F. Chung, A. Cendrero, and J. Remondo, "Is prediction of future landslides possible with GIS?" J. Nat. Hazards, vol. 30, no. 3, pp. 487-499, Nov. 2003.

[35] S. Sarkar and D. P. Kanungo, "An integrated approach for landslide susceptibility mapping using remote sensing and GIS," Photogramm. Eng. Remote Sens., vol. 70, no. 5, pp. 617-625, May 2004.

[36] J. A. Coe, J. W. Godt, R. L. Baum, R. C. Bucknam, and J. A. Michael, "Landslide susceptibility from topography in Guatemala," in Landslides: Evaluation and Stabilization, W. A. Lacerda et al., Eds. London, U.K.: Taylor \& Francis, 2004, pp. 69-78.

[37] L. Ayalew, H. Yamagishi, and N. Ugawa, "Landslide susceptibility mapping using GIS-based weighted linear combination, the case in Tsugawa area of Agano River, Niigata Prefecure, Japan," Landslide, vol. 1, no. 1, pp. 73-81, Mar. 2004.

[38] J. C. Davis, Statistics and Data Analysis in Geology. New York: Wiley, 1986, p. 646.

[39] P. J. Finlay, R. Fell, and P. K. Maguire, "The relationship between the probability of landslide occurrence and rainfall," Can. Geotech. J., vol. 34, no. 6, pp. 811-824, Dec. 1997.

[40] C. Irigaray, F. Lamas, R. E. Hamdouni, T. Fernandez, and J. Chacon, "The importance of the precipitation and the susceptibility of the slopes for the triggering of landslides along the roads," J. Nat. Hazards, vol. 21, no. 1, pp. 65-81, Jan. 2000.

[41] N. Caine, "The rainfall intensity-duration control of shallow landslides and debris flows," Geogr. Ann., vol. 62A, no. 1/2, pp. 23-27, 1980.

[42] P. Canuti, P. Focardi, and C. A. Garzonio, "Correlation between rainfall and landslide," Bull. Int. Assoc. Eng. Geol., vol. 32, pp. 49-54, 1985.

[43] M. C. Larsen and A. Simon, "A rainfall intensity-duration threshold for landslides in a humid-tropical environment, Puerto Rico," Geogr. Ann., vol. 75A, no. 1/2, pp. 13-23, 1993.

[44] J. Godt, "Observed and modeled conditions for shallow landslide in the Seattle, Washington area," Ph.D. dissertation, Dept. Environ., Population, Organismic Biol., Univ. Colorado, Boulder, 2004.

[45] G. Liritano, B. Sirangelo, and P. Versace, "Real-time estimation of hazard for landslides triggered by rainfall," Environ. Geol., vol. 35, no. 2/3, pp. 175-183, 1998.

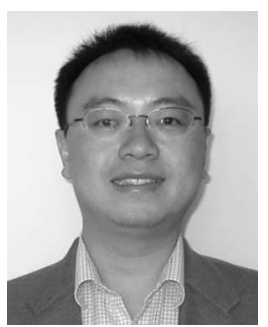

Yang Hong received the B.S. and M.S. degrees in geosciences and environmental sciences from Beijing (Peking) University, Beijing, China, and the $\mathrm{Ph} . \mathrm{D}$. degree, major in hydrology and water resources, and minor in remote sensing and spatial analysis, from the University of Arizona at Tucson.

$\mathrm{He}$ is a Research Scientist of remote sensing/ geospatial analysis and hydrology with the Goddard Earth Sciences and Technology Center/University of Maryland Baltimore County, Baltimore, at the National Aeronautics and Space Administration Goddard Space Flight Center, in Greenbelt, MD. He has over ten years of experience in water resources management and environmental planning. His current research involves monitoring large-area hydroclimatic hazards with remote sensed data and developing decision support tools.

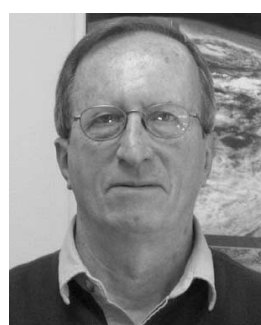

Robert F. Adler received the B.S. and M.S. degrees from Pennsylvania State University, University Park, in 1965 and 1967, respectively, and the Ph.D. degree from Colorado State University, Fort Collins, in 1974.

His research focuses on the analysis of precipitation observations from space on global and regional scales using Tropical Rainfall Measuring Mission (TRMM) data along with data from other satellites. He studies precipitation variations in relation to phenomena such as El Nino/Southern Oscillation, volcanoes, and tropical cyclones, as well as longer, interdecadal changes or variations. He also leads the group that produces the global monthly and daily precipitation analyses for the World Climate Research Programme Global Precipitation Climatology Project. He has published 80 papers in scientific journals on these topics. He is currently the TRMM Project Scientist.

Dr. Adler is a Fellow of the American Meteorological Society. He received the NASA Outstanding Leadership Medal in 2002, NASA Exceptional Scientific Achievement Medal in 1989, Goddard Laboratory for Atmospheres Scientific Leadership Award in 2002, and Goddard Space Flight Center-Exceptional Performance Award in 1980.

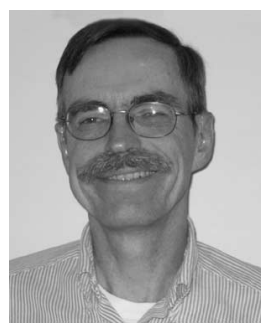

George Huffman received the B.S. degree in physics from The Ohio State University, Columbus, in 1976, and the Ph.D. degree in meteorology from the Massachusetts Institute of Technology, Cambridge, in 1982.

$\mathrm{He}$ is currently the Chief Support Scientist with Science Systems and Applications, Inc., Lanham, MD. His recent professional activities are design/ implement/extend satellite gauge model global rainfall estimation, combining Special Sensor Microwave/Imager (SSM/I), geosynchronous IR, gauge, and TIROS Operational Vertical Sounder (TOVS) data; estimate rms error in such data sets; produce Global Precipitation Climatology Project (GPCP) and Pathfinder data sets using SGM for 1979 to (delayed) present; design/implement $1^{\circ}$ daily combination for GPCP; develop TRMM algorithms 3B-42 and 3B-43, develop/implement TRMM Multisatellite Precipitation Analysis for TRMM in both real time and postreal time. His professional interests include observational and theoretical mesoscale and synoptic meteorology, including precipitation retrievals from satellite and other sensors, retrieval errors, cumulus convection, and forecasting. He has 46 refereed publications, as well as numerous conference and seminar presentations.

Dr. Huffman received the NASA/GSFC Mesoscale Atmospheric Processes Branch Exceptional Technical Support Award in 2004 and NASA/GSFC Laboratory for Atmospheric Contractor Award for Outstanding Performance in Science in 2002. 